\title{
Erratum: Social justice, corporate social responsibility and sustainable development in South Africa
}

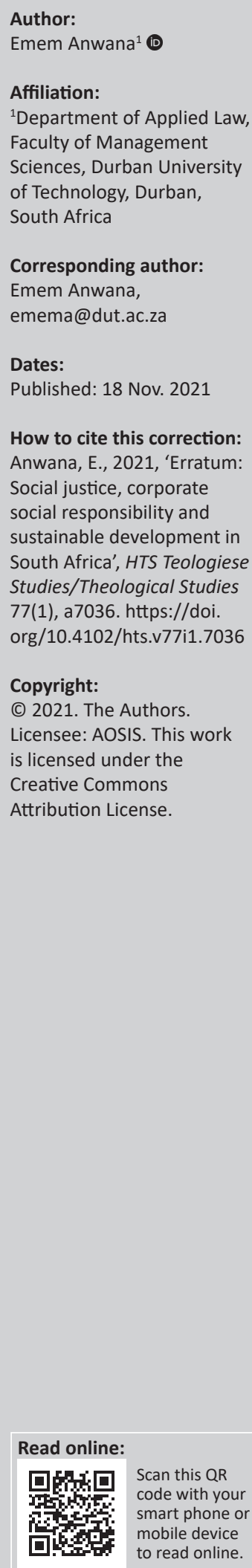

In the version of this article initially published, Anwana, E., 2020, 'Social justice, corporate social responsibility and sustainable development in South Africa', HTS Teologiese Studies/ Theological Studies 76(3), a6095. https://doi.org/10.4102/hts.v76i3.6095, the caption for Table 2 was given incorrectly. The correct caption should be 'Rotated component matrix indicating the variables that constitute factors that motivate South African businesses to implement corporate social responsibility' instead of 'Rotated component matrix $x^{a}$ indicating the variables that constitute the most challenges to South African businesses when implementing corporate social responsibility'.

This correction does not alter the study's findings of significance or overall interpretation of the study results. The publisher apologises for any inconvenience caused. 


\section{Social justice, corporate social responsibility and sustainable development in South Africa}

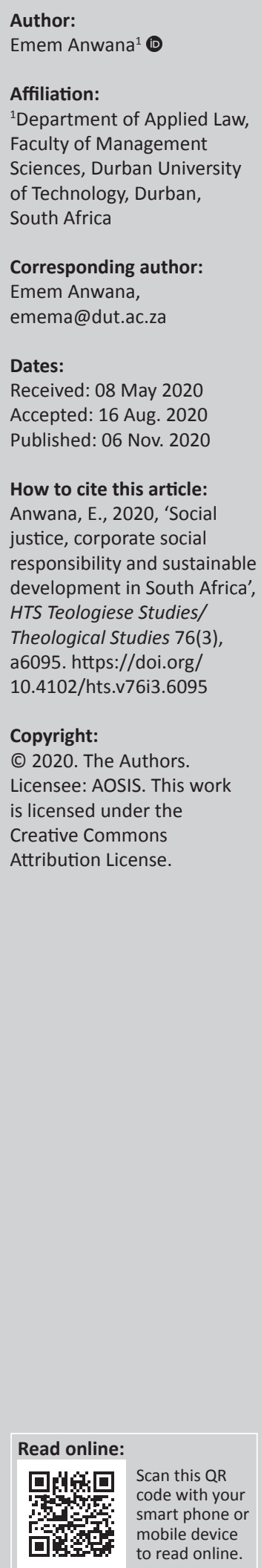

South Africa is a country that is still in the transitioning process of providing an equal, equitable and just society for its previously disadvantaged people. The country faces several socio-economic developmental challenges, ranging from inadequate housing, high crime rates, violence against women and children, ineffectual health facilities, a slowing economy and high youth unemployment, which invariably affect the business community. If South Africa is to achieve sustainable economic transformation, the business community along with other stakeholders must participate in ensuring social justice and socio-economic development for its previously disadvantaged people. This article contributed to the discourse on the assertion that social justice and socio-economic development are central for sustainable development in any society. The article called for the assistance and participation of other stakeholders, particularly the business community, to help build a just, healthy and robust environment, which translates into a strong community and portends a sustainable environment for businesses.

Contribution: This article assessed the effectiveness of legislating social justice and corporate social responsibility. The article adopted the European Union's Better Regulation evaluation methods to evaluate the effectiveness of the country's social justice and corporate social responsibility legislation and the influence of the legislations on the socio-economic developmental challenges affecting the country.

Keywords: Social justice; Socio-economic development; Sustainable development; Corporate social responsibility; Legislation; Law; Business.

\section{Introduction}

South Africa is a country that is faced with unique and distinctive socio-economic challenges that are generally attributed to the legacy of the apartheid regime (Govender 2016; Reddy 2016). The country is considered to be one of the most unequal societies in the world because of the wealth disparity that exists between the rich and poor (Babarinde 2009; Govender 2016; Ramlall 2012). White South Africans are largely affluent, whereas the majority of black South Africans are impoverished and living in townships, squatter camps and informal settlements (Chikulo 2013; Govender 2016; Madlanga 2019; Wilson 2011). The socio-economic situation that the country faces suggests an unsustainable business environment for any business or government. According to Mariri (2012), if the situation remains uncontrolled, it could ultimately subvert the country's social and economic cohesion, consequently destabilising the economy.

The apartheid system was based on the racial classification of people, wherein one race (white minority) was made superior and therefore controls and retains political and economic dominance over the majority of black population. The apartheid government stripped black African's of their right to land ownership and forcefully removed them from their ancestral lands as a means of securing and maintaining white political domination and economic exploitation (Henrard 1996). The establishment of the Black Land Act of 1913 restricted and limited African people's ownership and occupation of land. According to Henrard (1996), this singular policy was the sole reason why apartheid was so successful and lasted for the better part of 50 years. According to the author, the unjust, punitive and untenable allocation of land and rights to land resulted in the unjust, inequitable and brutal social order that became South Africa (Henrard 1996). Control of access to land allowed white minority capitalists to control agriculture, mining, industry, commerce and the economy of the nation, to the exclusion of the black majority. This resulted in the problem of low economic viability within the black population leading to the majority falling into extreme poverty (Henrard 1996). The Truth and Reconciliation Commission (TRC) that was set up to 
reconcile South Africans failed to offer compensation to the victims of apartheid nor did it compensate black South African's for the gross violations of human rights and land dispossession's that occurred (Helliker, Hendricks \& Ntsebeza 2013). Based on this history, race, land and economic exclusion play a major role in social justice, socio-economic development and sustainable development discourse in South Africa (Davis 2020; Tshishonga 2019).

After the elections in 1994, the African National Congress (ANC)-led government set about dismantling apartheid legislation and promulgating new legislation in an attempt to redress past injustices and to ensure the participation of black South Africans, both politically and economically (Babarinde 2009). In a report highlighting the country's economic and social indicators since the end of apartheid in 1994, it is shown that South Africa is still faced with multiple challenges, which include high youth unemployment, high-income disparity between the lower-income categories and middle- to upper-class categories, dwindling contributions by the mining and manufacturing sectors, labour uncertainties, weak education and health systems and an under-performing public sector (Goldman Sachs 2013; Tshishonga 2019). In view of this, it is essential that there exists an enabling and sustainable business environment within which companies can operate to provide employment for the country's unemployed youth. The business community needs to play a role in correcting some of the anomalies that persist in the country (Babarinde 2009). This article contributes to the discourse that there exists a correlation between the attainment of social justice through corporate social responsibility (CSR) implementation and business sustainability (Anwana 2018; Reddy 2016). The article adopts the European Union's (EU) Better Regulation evaluation methods to evaluate the effectiveness of the country's social justice and CSR legislation and the influence of these legislations on the socio-economic developmental challenges affecting the country.

This article is divided into three segments. The first segment explores CSR and its relationship with social justice within the South African legislative context. The second segment explores the challenges arising from the actualisation of social justice through CSR implementation amongst South African companies, whilst the third segment of the article discusses the research methods, findings, recommendations and conclusions arising from a study conducted by Anwana (2018) adopting the EU's Better Regulation evaluation methods to evaluate the effectiveness of social justice and CSR legislation in South Africa and their influence on socioeconomic development.

\section{Literature review}

\section{Social justice, corporate social responsibility and socio-economic development in South Africa}

Social justice is described by Neier (2013) as being about the distribution or redistribution of wealth and resources. Saiz and Yamin (2013) postulated that the concept is a broad framework that incorporates the principles of human rights, equity and participation. Watson (2019) asserts that social justice is an undimensional term that appears to equate with equality or equal opportunity and contends that individuals and organisations must ensure social justice through recognising and upholding diversity and inclusion, as well as showing empathy for the enormity of trauma that people had been subjected to.

In South Africa, social justice is often linked to economic exclusion, mainly because of the country's past and the present realities it faces (Davis 2020). South Africa is one of the few countries in the world which enshrines social justice in its constitution. The 1996 Constitution in its preamble states that the Constitution was intended to, amongst other things, ensure 'social justice and fundamental human rights'. The equality clause in Section 9 states that 'everyone is equal before the law and has the right to equal protection and benefit of the law'. The section goes on to describe equality as including 'full and equal enjoyment of all rights and freedoms' and permits legislative and other measures to be taken to advance or protect persons who were disadvantaged by unfair discrimination (South African Government 1996).

The role of South African corporates in sustaining the apartheid regime is well-documented. Tshitereke and Crush (2001) catalogued how mining companies benefitted from the draconian labour laws of the apartheid regime. Babarinde (2009) similarly contended that South African businesses contributed to and benefitted from apartheid rule; therefore, it is only fitting that they also assist in 'righting the wrongs of the past' as well as ensuring a sustainable business environment that would provide jobs for the unemployed youth and contribute to ensuring social justice and socioeconomic development for the South African people.

The ANC government, in its quest to empower the majority black population who were excluded from participating in the country's economy by the apartheid government, launched various economic and industrial policies when it came into power in 1994. The first of these was the Reconstruction and Development Plan (RDP) of 1994, followed by the Growth, Employment, and Redistribution (GEAR) initiative in 1996. The Accelerated and Shared Growth Initiative for South Africa (ASGISA) was launched in 2006 with the aim of halving poverty and unemployment (The Presidency 2007). These policies were primarily aimed at ensuring sustainable economic growth for the country, providing a platform for diversity in business ownership and more importantly helping to steer private capital towards investment in social issues such as the HIV pandemic, education and skills development as well as ensuring social justice through private sector involvement in the socioeconomic development of the previously disadvantaged population (Ramlall 2012; Reddy 2016; Tshishonga 2019).

An assessment of these policies 25 years after the demise of apartheid observes that most of these policies have regrettably failed in their quest to ensure social justice and 
socio-economic development in South Africa (Anwana 2018). Reasons canvassed for their failures range from the slow rate of national economic growth, lack of growth of employment in the agricultural sector because of the failed 'willing buyer willing seller' land reform initiatives, poor service delivery in provision of water, electricity, education and health facilities to the impoverished areas of South Africa as well as lack of meritocracy amongst those holding political powers within the ANC government (Karriem \& Hoskins 2016). According to Davis (2020), embracing social justice within the South African context means 'the ability of all South Africans to live a dignified life through fair and reasonable participation in the economic intercourse of the country'. The author maintains that without economic inclusion, social justice in South Africa cannot be achieved.

In its attempt to ensure the economic inclusion of previously disadvantaged people and redress past injustices, the South African government embarked on more legislative and economic reform policies aimed at ensuring that businesses play a significant role in the socio-economic development of the country (Babarinde 2009). The government set about creating corporate social investment (CSI) obligations for businesses. Such obligations included increasing the participation of black people in the ownership of businesses, creating social and ethical obligations for companies to comply with; and creating preferential jobs and business opportunities for black people through measures such as affirmative action and preferential procurement (Chikulo 2013; Madlanga 2019; Reddy 2016). The Broad-Based Black Economic Empowerment (BBBEE) Act of 2013, the Companies Act of 2008, the King IV Report on Corporate Governance 2016, the Employment Equity Act (EEA) 1998 and the Preferential Procurement Act 2000 are generally regarded as the government's flagship initiatives for social justice and CSR in South Africa (Reddy 2016). These legislative measures are discussed in the next segment of the article as they relate to social justice and CSR implementation.

\section{The Broad-Based Black Economic Empowerment Act of 2013}

Mariri (2012) identified the Black Economic Empowerment policy (BEE) as a strategic initiative of the ANC government aimed at promoting economic transformation through ensuring meaningful participation of previously disadvantaged people in the South African economy. The broad aim of the Act as noted by Reddy (2016) was to remedy the organisational inequalities of the apartheid rule by steadily and legally redistributing equities to the previously disadvantaged black population. The Act also aimed at diversifying the workplace through development of skills and generally promoting the development of black people in all spheres of life (Akinsomi et al. 2016; Babarinde 2009).

The Act created not only legal but social perceptions that compliant BBBEE firms were socially responsible firms, thus granting such firms access to government tenders and other financial incentives for implementing the BBBEE policy
(Akinsomi et al. 2016; Alessandri, Black \& Jackson 2011). Compliant companies could gain access to new markets and opportunities in both the public and private sectors, as well as benefit from favourable media coverage and increased corporate reputation, particularly amongst the newly economically empowered black South Africans who now had the resources to impact a company's profit margin (Thomas 2014).

However, 25 years and after various amendments to the BBBEE Act, scholars, business managers and critics have judged the Act as having failed to advance the plight of the previously disadvantaged people nor helped to right the wrongs of the apartheid government against the black population (Anwana 2018). The Act has rather been criticised for, creating 'black elites' and promoting corrupt practices by companies through 'fronting' and other corrupt practices. Black people themselves have criticised the Act as simply a disguise to pacify an impatient black populace (Babarinde 2009; Reddy 2016). According to Alessandri et al. (2011), although many positives can be ascribed to BBBEE in relation to a firm's financial performance when seen to be compliant, there are arguments that suggest that the BBBEE Act did not create the anticipated values, but may have destroyed the corporate values for participating organisations. Therefore, the extent to which the BBBEE has impacted on social justice and the socio-economic development of South Africa is still debatable.

\section{The Companies Act No. $\mathbf{7 1}$ of 2008}

The Companies Act No. 71 of 2008, as amended by the Companies Amendment Act No. 3 of 2011 and the Companies Regulations (2011), introduced fundamental changes to South African company laws and corporate actions (KPMG 2017a). The objective of the Act aimed at broadening stakeholder engagement in company actions and providing for improved regulation of corporate activities, particularly in the areas of accountability and transparency (Ramlall 2012). With regard to social justice and socio-economic development, the Act introduced the imperative for the establishment of a Social and Ethics Committee (SEC) to enable companies manage their social responsibility and stakeholder issues in a more responsible manner (KPMG 2017a). The most significant function of the Companies Act is to provide the legal platform for the King Report on Corporate Governance, which without the Act creates no legally binding obligations on South African businesses.

\section{The King IV report on corporate governance and social justice in South Africa}

King IV became operational in April 2017. According to PWC (2016), King IV is an acknowledgement that an organisation does not operate in a vacuum, but as an integral part of society and should, therefore, be accountable towards its present and future stakeholders (PWC 2016). King IV focuses extensively on the accountability and transparency of companies towards a broader stakeholder base within a 
wider society and embeds the philosophy of 'integrated thinking' throughout the Code, with recommendations that a company should present the company's material information in an integrated manner by issuing reports annually (Deloitte 2017). The Report recommends that company boards should ensure that the organisation is seen to be a responsible corporate citizen. To achieve this, the board or governing body is to set policies for good corporate citizenship, which would include compliance with laws, standards and the company's own policies and procedures. Corporations are required to monitor and manage the organisation's standing as a good corporate citizen and divulge how corporate citizenship is managed (KPMG 2017b).

One of the most distinguishing features of King IV that significantly impacts on CSR and social justice is its abandonment of the 'Apply or Explain' approach of King III in favour of the 'Apply and Explain' approach (KPMG 2017b). Hence, with regard to CSR implementation and compliance with CSR legislation, organisations no longer have the option of explaining non-compliance with the recommended principles, and they are now required to apply the recommendations of the Report in all its material ramifications.

Principle 13 of the King IV Report provides that an organisation's governing body is required to ensure that their organisation complies with applicable laws adopt rules, codes and standards that ensure that the organisation is ethical and a good corporate citizen. An organisation is seen as a good corporate citizen when, according to Rahim and Alam (2014), the organisation incorporates issues such as social justice, human rights, workers' rights, environmental protection as well as democratic values into its corporate governance strategies. In the context of South Africa's historical antecedents and the socio-economic realities, there is a growing need for business directors to ensure that their companies act as responsible corporate citizens by promoting social justice and investing in the socio-economic development of the communities in which they operate (Reddy 2015, 2016; Rossouw 2016). As observed by Babarinde (2009), if South African businesses do not conform to these recommendations, South Africa may not have a sustainable business environment for continued economic growth, which it requires so badly (Skinner \& Mersham 2008).

\section{The Employment Equity Act No. 55 of 1998}

To ensure that the reform initiatives transcended corporate ownership and participation and flowed into the realm of employment, the EEA was legislated in 1998. The EEA serves as the main legislative attempt by the South African government to prevent unfair and discriminatory practices in the workplace against a previously disadvantaged, largely black impoverished population (Horwitz \& Jain 2011). The main aim of the Act is to remove all barriers to employment experienced by members of the previously disadvantaged groups, referred to by the Act as 'designated groups'. Section 1(b) of the 2013 Amendment Act defines 'designated groups' as black people, women and people with disabilities who are citizens of the Republic and who were excluded by apartheid policies (Department of Labour 2017).

The EEA sought to create a representative workforce as well as transform the South African workplace into one that is more balanced and representative of the country's demography. It aimed to ensure a workplace governed by principles of equality through the application of affirmative action measures (Mushariwa \& Papacostantis 2016). Section 15 defines affirmative action measures as (Department of Labour 2017):

$[M]$ easures designed to ensure that suitably qualified people from designated groups have equal opportunities and are equitably represented across all occupational categories and levels in the workforce of a designated employer. (s. 15)

Like the BBBEE, the EEA has received its fair share of criticisms from scholars and business managers alike. Louw (2015) criticised the affirmative action provisions of the Act as discriminatory, unconstitutional and in direct contradiction to Section 9 of the Bill of Rights, which guarantees everyone's equality before the law and prevents discrimination of any kind (Currie \& De Waal 2013). According to Louw (2015), employers who implement affirmative action policies stand the risk of being subjected to unfair discrimination claims. Hence, he calls for its abolishment.

\section{Preferential Procurement Policy Framework Act, 2000}

South Africa is one of the few countries in which preferential procurement is provided for in the Constitution (Watermeyer 2003). Section 217(3) of the 1996 Constitution, provides that 'national legislation must prescribe a framework within which preferential procurement policy may be implemented' (South African Government 2019). In response to this provision, the Preferential Procurement Policy Framework Act (PPPFA; Act 5 of 2000) was enacted by the national legislators (Madlanga 2019).

The Preferential Procurement Policy was established to provide 'historically disadvantaged individuals' the opportunity to participate in the nation's economy through State procurement processes (Hlakudi 2015). The policy creates a set number of preference points based on a contractor's BBBEE status level. The regulations provide for the procurement of locally produced goods, services and works, as well as locally manufactured goods within designated sectors (Bolton 2011).

Scholars and business managers alike have noted that although many positives can be derived from the preferential procurement policy, many unintended consequences may also arise. For example, Watermeyer (2003) noted that it is always concerning when procurement is used as an instrument of social policy, as it could undermine primary procurement objectives and give room to inefficiency in procurement. It could result in the exclusion of eligible 
tenderers from competing for tenders, a reduction in competition and failure to achieve the socio-economic objectives through procurement. According to Madlanga (2019), Parliament missed an opportunity to bring about true equality in passing the PPPFA. The author contends that even the name of the Act - PPPFA - is a misnomer as the preference envisaged in Section 217(2) of the Constitution is simply non-existent. Madlanga (2019) contended that there are only five factors at the heart of Section 217(1) of the Constitution for which an organ of state must procure goods and services, and they are fairness, equity, transparency, competitiveness and cost-effectiveness, and not the colour of one's skin.

\section{Legal compliance challenges of implementation of social justice and corporate social responsibility}

Although legislative imperatives exist along with a historical necessity to motivate companies and businesses in South Africa to invest in social justice and socio-economic development, such investments are not without significant challenges. It is therefore factual to aver that South African companies are faced with various forms of challenges when investing in social justice and socio-economic development. According to Reddy (2016), the existence of various social justice and CSR legislation in South Africa has influenced to a large extent business involvement in socio-economic development and the attainment of some form of social justice in the country. However, the author admits that businesses are met with numerous challenges when it comes to the implementation of the various legislations.

These challenges include stakeholder expectations/ management, government interference, weak regulatory systems, skills shortages and corruption (Da Piedade \& Thomas 2006; Frynas \& Yamahaki 2016; Hamann 2005; Hinson \& Ndhlovu 2011; Preuss, Barkemeyer \& Glavas 2016; Visser 2005; Waweru 2014; Young 2010). The challenges have major implications for social justice and CSR attainment and implementation.

\section{Stakeholder expectations}

In very poor communities, high stakeholder expectations may overwhelm companies, thereby affecting their CSR policies (Preuss et al. 2016). In South Africa, apartheid policies of preventing the majority black population from participation in the nation's economy left the country and the majority black population with high levels of poverty, illiteracy and other forms of social and economic inequality (Reddy 2015), hence aggravating levels of unemployment and poverty and by implication, elevated levels of dependency on grants and charities leading to overwhelming expectations for companies operating in local areas and government departments alike (Chikulo 2013).

Apart from poverty, the HIV/AIDS pandemic became a serious challenge to the South African workforce. Many
South African companies had to report on the impact of HIV / AIDS in their annual reporting, as well as develop and implement policies to manage the effect of the epidemic on their operations (Rampersad 2010). Foreign investors and South African companies alike are often overwhelmed by the complex social dynamics of their host country and its communities. According to Preuss et al. (2016), sometimes these complexities may be competing, thus not permitting companies to perform well within the social justice and CSR dimensions.

\section{Government interference}

According to Waweru (2014), developing countries are often confronted by a myriad of problems, including ineffective legislative policies that look great on paper, but are difficult to implement and enforce. Others include weak legal controls and frequent government interventions. Although South Africa is highly rated in terms of corporate governance structures, businesses in the country still suffer in terms of frequent government interference in their internal affairs. Examples of such interference are the BBBEE policies, the various labour policies and other legal regulatory frameworks. According to Hinson and Ndhlovu (2011), most business involvement in socio-economic developmental projects is influenced mainly as a result of government regulation and interventions through legislative measures. Reddy (2016) cautioned against using legislative measures to force the private sector to adopt socially responsible measures, as this could erode foreign confidence and investment in the country (Ramlall 2012; Reddy 2016).

\section{Skills shortages}

Availability of skills constitutes a fundamental operational problem for many South African companies (Kraak 2008; Mxunyelwa \& Vallabh 2017; Radipere \& Van Scheers 2014). According to Radipere and Van Scheers (2014), many businesses in South Africa fail as a result of a lack of managerial and corporate leadership skills. As noted by Waweru (2014), 'most developing economies suffer from a lack of skilled human resources, and experience difficulties attracting people with accounting or financial knowledge to their organisations'. This will in turn affect the ability of companies to implement CSR projects, which will impact the socio-economic demands of their communities (Preuss et al. 2016). Without the required skills, particularly in accounting and finance, the involvement of businesses in CSR and social justice implementation will be very difficult to achieve (Waweru 2014).

\section{Corruption}

Corruption is a devastating, harmful and destructive phenomenon that can stunt the economic growth of a country, corrode the social structure of a nation and distort economies (Arafa 2011). Corruption in South Africa has been described as pervasive. According to Luiz and Stewart (2014), where corruption is pervasive, companies face an operational paradox that involves cost, erodes corporate 
ethics and in some cases promotes fraud and illegality. This adversely affects a company's investment in socio-economic development projects. Therefore, for companies to participate in social justice and socio-economic development, putting an end to corruption must be an urgent priority, without which it would be impossible for South African corporates to invest in the socio-economic development of their communities, people or environment (Arafa 2011; Madlanga 2019).

\section{Ethical considerations}

This article followed all ethical standards for research without direct contact with human or animal subjects.

\section{Methodology and discussion of findings}

To measure and evaluate the influence of the above-discussed legislation on social justice attainment, CSR implementation and its impact on socio-economic development in South Africa, this article adopts the EU's Better Regulation Guidelines to analyse the findings obtained by Anwana (2018) in a study on how legislative intervention impacts on social justice and CSR implementation amongst South African companies.

The EU's Better Regulation Guidelines have been used in the EU for over 20 years, to inform policymaking by assessing the fitness of existing policy interventions to determine the economic, social and environmental impacts of legislative interventions (European Commission 2017). At a minimum, the evaluation process involves an evidence-based fitness check of the extent to which an existing intervention is effective, efficient, relevant and coherent and if there is any added value to economic, social and environmental issues (European Commission 2017). This article adopts these guidelines to conduct an evaluation of the flagship legislative interventions of the South African government towards the attainment of social justice, CSR implementation and socioeconomic development.

Although South Africa has an equivalent evaluation framework known as the National Evaluation Policy Framework (NEPF) established in 2011 (The Presidency 2011), the national evaluation systems (NESs) only became evaluative in 2016 to determine whether it had any impact on the government programmes and policies it evaluated. Whilst it is established that certain programmes evaluated by the NES did receive benefits, for example, the evaluation of the Early Childhood Development (ECD) policy resulted in recommendations for an expansion of the focus to include the first 1000 days of the child from conception (Goldman et al. 2019). This has been seen as a major achievement because if implemented it would impact government policies in relation to maternal health policies and child grant policies. However, an evaluation of the impact of social justice and CSR legislation has not commenced in South Africa. Hence, this article adopts the EU's Better Regulation Guidelines as a tool to assess the impact of social justice and CSR legislation within the South African context. It is pertinent to note, however, that the EU's Better Regulation Guidelines have received several criticisms. For example, European trade unions have criticised it as being packaged to put the needs of business above all others, adding to red tape, slowing down progressive change and de-democratising Europe (Schout \& Schwieter 2018).

The first step of the EU evaluation is to understand the background, context and current situation of an intervention. The group of legislative interventions examined in this article are the BBBEE Act, the 2008 Companies Act, the EEA, Preferential Procurement Act and the King IV Report. This collection of initiatives were designed to ensure social justice by attempting to right the wrongs of the past apartheid regime, through the inclusion and participation of previously disadvantaged groups in the nation's economy. The interventions aimed at achieving these objectives by encouraging corporate investment in the area of social justice, CSR and corporate governance (Reddy 2016). The background and context of these interventions are clearly highlighted in the literature review of this article.

The second step in the EU fitness evaluation is premised on investigating the effectiveness of the intervention. This is achieved by analysing the progress made towards achieving the objectives of the intervention, looking for evidence of why, whether or how these changes are linked to the intervention (European Commission 2017). This article, thus, explored the question: How effective has legislating social justice and CSR impacted on socio-economic development and sustainable business environment? The literature section of this article expounded on the notion that businesses could contribute to the attainment of social justice in South Africa through CSR implementation. The literature also highlighted the challenges faced by businesses in implementing CSR. Corruption, government interference, shortages of skills, stakeholder's high expectations, legal compliance and weak regulatory systems were identified as some of the challenges faced by South African companies in CSR implementation, thereby impacting on the attainment of social justice and by implications of socio-economic development and business sustainability (Arafa 2011; Madlanga 2019).

In the research conducted by Anwana (2018), respondents were asked about areas where CSR implementation was most challenging for their companies. The results indicated that legal compliance was the most challenging aspect of CSR implementation for most South African listed companies. This was closely followed by weak regulatory systems and shortages of skills. Using the EU fitness evaluation this is an indication that existing legislative interventions by the South African government are not deriving the benefits it aims to achieve, rather the plethora of social legislation seems to discourage or hamper companies from investing in social justice and socio-economic developmental causes in the country. As observed by Anwana (2018), where compliance with legislation is forced and coerced, business managers tend not to practice strategic CSR but rather invest in feel- 
good projects that ultimately will have no long-term impact on the society. Similarly, according to Hafenbrädl and Waeger (2017), where business managers consistently view social investment as reducing company financial performance, they will continue to refrain from investing in socio-economic developmental projects. Table 1 is the rotated component matrix which indicates the variables that constitute the most challenges to South African businesses when implementing CSR.

The third step in the evaluation process investigates the efficiency of legislating CSR and social justice. The evaluation assesses both the costs and benefits of the intervention as they accrue to different stakeholders, identifying factors driving these costs/benefits and how these factors relate to the intervention (European Commission 2017). In the study, companies were asked what motivated them to implement CSR. The results indicated that most companies considered their employee satisfaction, philanthropy, business ethics and environmental protection as some of the factors that motivate them the most to implement CSR. Table 2 is the rotated component matrix indicating the correlation between the various components.

The study revealed that the efficiency of the legislative interventions is compromised because companies will invest in CSR for reasons other than to comply with CSR legislation or to avoid punitive measures as consequences of non-compliance. It, therefore, means that legislation is less considered when companies invest in CSR implementation. Conversely, therefore, legislative interventions may result in companies refraining from CSR investments, particularly if they feel coerced or forced to invest (Anwana 2018).

The fourth step of the fitness evaluation process focuses on establishing coherence between the interventions. This explores how beneficial the interventions have worked both internally and in relation to the other related interventions to achieve a common objective (European Commission 2017). Table 3 indicates the benefits perceived by companies

TABLE 1: Rotated component matrix indicating the variables that constitute the most challenges to South African businesses when implementing corporate social responsibility.

\begin{tabular}{lcc}
\hline Challenges to CSR implementation & \multicolumn{2}{c}{ Component } \\
\cline { 2 - 3 } & 1 & 2 \\
\hline Legal compliance challenge & 0.873 & 0.102 \\
Financial constraints & 0.721 & 0.125 \\
Skills challenge & 0.830 & -0.040 \\
Weak regulatory systems & 0.835 & 0.197 \\
Stakeholder management & 0.802 & 0.315 \\
CSR distracts/detracts from core discipline of company & 0.810 & -0.038 \\
Government interference such as dealing with regulations & 0.707 & 0.497 \\
Corruption & 0.024 & $\mathbf{0 . 9 5 9}$ \\
\hline
\end{tabular}

Source: Anwana, E.O., 2018, 'Corporate social responsibility and corporate governance: Implementation and challenges for companies listed on the Johannesburg securities exchange', PhD thesis, Department of Applied Law, Durban University of Technology.

Note: Extraction method: principal component analysis. Rotation method: Varimax with Kaiser normalization.

CSR, corporate social responsibility.

aRotation converged in three iterations. on their compliance with CSR legislation. The component matrix indicates that legislative interventions although not the most important reasons why companies invest in CSR; however, companies did realise that compliance with CSR legislative interventions benefitted them in terms of improved corporate governance, enhancing motivation and trust amongst their employees, helping the company to become more responsible towards their stakeholders and helping the company's reputation in being perceived as a responsible organisation.

\section{Conclusion and recommendations}

This article focused on illustrating the correlation between CSR, social justice, socio-economic development and the creation of an enabling and sustainable business environment for the growth of South African businesses. The article explored the attempts by government to legislate into existence social justice and CSI. The article points out the

TABLE 2: Rotated component matrix ${ }^{a}$ indicating the variables that constitute the most challenges to South African businesses when implementing corporate social responsibility.

\begin{tabular}{lccc}
\hline Motivation to implement CSR & \multicolumn{3}{c}{ Component } \\
\cline { 2 - 4 } & 1 & 2 & 3 \\
\hline Ethical motivation & 0.740 & -0.260 & 0.202 \\
Environmental protection & 0.671 & 0.057 & 0.136 \\
\hline To promote corporate image and reputation & 0.573 & 0.371 & 0.309 \\
\hline Shareholder's satisfaction & 0.398 & 0.515 & 0.279 \\
\hline Increase of corporate income and profit & 0.504 & 0.415 & 0.311 \\
\hline Greater employee satisfaction & 0.770 & 0.173 & -0.072 \\
\hline $\begin{array}{l}\text { Benefit in relationship with government } \\
\text { institutions and community }\end{array}$ & 0.269 & 0.448 & 0.128 \\
Increase in corporate profitability & 0.423 & 0.346 & 0.566 \\
\hline Pressure from consumer association and media & -0.091 & 0.004 & 0.900 \\
\hline Compliance with CSR legislation & -0.175 & 0.831 & 0.002 \\
\hline $\begin{array}{l}\text { Philanthropy. i.e. donations } \\
\text { Avoidance of punitive measures/consequences } \\
\text { of non-compliance against company }\end{array}$ & -0.123 & -0.232 & -0.237 \\
\hline
\end{tabular}

Source: Anwana, E.O., 2018, 'Corporate social responsibility and corporate governance: Implementation and challenges for companies listed on the Johannesburg securities exchange', PhD thesis, Department of Applied Law, Durban University of Technology.

Note: Extraction method: principal component analysis. Rotation method: Varimax with Kaiser normalization.

CSR, corporate social responsibility.

aRotation converged in seven iterations.

TABLE 3: Component matrix ${ }^{\mathrm{a}}$

How has compliance with CSR legislation benefited your company? Component

\begin{tabular}{lc} 
& 1 \\
\cline { 2 - 2 } $\begin{array}{l}\text { Compliance with CSR legislation has helped improved our companies' } \\
\text { profitability }\end{array}$ & 0.730 \\
$\begin{array}{l}\text { Compliance has helped in creating awareness about the need to } \\
\text { protect the environment in our company }\end{array}$ & 0.744 \\
$\begin{array}{l}\text { Community are less hostile and more supportive of our companies' } \\
\text { activities }\end{array}$ & 0.729 \\
$\begin{array}{l}\text { Compliance has helped our company to become more responsible } \\
\text { towards stakeholders, particularly with communication }\end{array}$ & 0.818 \\
$\begin{array}{l}\text { Compliance has improved corporate governance in my company } \\
\begin{array}{l}\text { Compliance with CSR legislation has enabled our employees to be } \\
\text { more motivated and more trusting of the company }\end{array}\end{array}$ & 0.897 \\
$\begin{array}{l}\text { Compliance has helped the company to be perceived by its stakeholders } \\
\text { as a more sustainable, accountable and responsible organisation }\end{array}$ & 0.833 \\
\hline
\end{tabular}
as a more sustainable, accountable and responsible organisation

Source: Anwana, E.O., 2018, 'Corporate social responsibility and corporate governance: Implementation and challenges for companies listed on the Johannesburg securities exchange', PhD thesis, Department of Applied Law, Durban University of Technology. Note: Extraction method: principal component analysis.

CSR, corporate social responsibility.

aOne component extracted. 
unintended consequences of the legislative measures or interventions and espouses that there may be a need for government to consider amendments to some of the legislation to eschew some of the negative unintended consequences brought about by these legislation. The following are the recommendations for South African businesses and government agencies when investing in social justice and CSR.

\section{A shift from short-term to long-term corporate social responsibility}

South African companies need to move from the present short-term reactive investment in social issues to a more consistent long-term corporate interest in social justice and socio-economic development of communities in which they carry out their operations (Michelon, Boesso \& Kumar 2013). According to Mersham and Skinner (2016), South African businesses need to play a more proactive and involved role in issues of social justice and socio-economic development if they themselves are to realise a sustainable business environment within which to operate (Babarinde 2009; Reddy 2016). Babarinde (2009) emphasised that it is time for South African companies to eschew the 'hand-out' or giving 'something back' approach in dealing with socio-economic issues. Rather, they should adopt a long-term approach where they can be seen not only as investing in local communities but also as partnering with the communities.

\section{Constant modification and development}

Flores-Araoz (2011) maintains that corporations should invest in social justice and socio-economic developmental needs and demands of their host communities, particularly those communities that were dehumanised, neglected and exploited by the apartheid regime. The author, however, cautions against a 'hands-off/once-off' approach and advocates for a more informed and involved initiative, one that attracts constant modification and development for such investments to remain relevant to the changing dynamics of the communities.

\section{Integrated reporting}

Principle 5 of the King IV Report and the listing requirements of the Johannesburg Stock Exchange (JSE) advocate for companies to adopt an integrated reporting framework (Bhasin 2017). According to Adams (2015) integrated reporting has the 'potential to change the thinking of corporate actors, leading to further integration of sustainability actions that impact corporate strategic planning and decision-making'. Trialogue (2014) maintained that corporations need to move away from the sharing of happy stories about their social investment in their reporting to showing demonstrable, provable and verifiable results of the impact of social investment on their company's triple bottom line. A company's investment in CSR implementation and social justice will only be successful when businesses begin reporting on their social investment as being vital to their past or future performances (Carroll 2008).

\section{Measuring and evaluating the impact of corporate social responsibility and social justice on business sustainability}

CSR scholars and researchers have called for the need to measure, monitor and evaluate CSR and social spending (Prasad \& Kumar 2011; Rampersad 2015; Rossouw 2016). Businesses need to develop indicators to help in measuring and evaluating the achievements and contributions of their social investment to their fiscal performance, as well as on their target population (Archer 2015; Mersham \& Skinner 2016). According to Carroll (2008), a company's socioeconomic investment can only be successful if it adds to the company's bottom line and is specifically delineated as having made such an impact. The monitoring and evaluation (M\&E) of developmental programmes affords companies a more effective technique for learning from previous experiences, improving their service delivery system, developing more methodical planning and optimising of resource allocation as well as demonstrating outcomes as part of their accountability to key stakeholders (Prasad \& Kumar 2011; Trialogue 2014).

\section{Acknowledgements}

The author thanks the Durban University of Technology and Professor Karunanidhi Reddy for the support provided in conducting this research article.

\section{Competing interests}

The author declares that she has no financial or personal relationships that may have inappropriately influenced her in writing this research article.

\section{Author's contribution}

E.A. is the sole author of this article.

\section{Funding information}

This research received no specific grant from any funding agency in the public commercial or not-for-profit sectors.

\section{Data availability}

Data sharing is not applicable to this article as no new data were created or analysed in this study.

\section{Disclaimer}

The views and opinions expressed in this article are those of the author and do not necessarily reflect the official policy or position of any affiliated agency of the author.

\section{References}

Adams, C.A., 2015, 'The international integrated reporting council: A call to action', Critical Perspectives on Accounting 27(C), 23-28. https://doi.org/10.1016/j. сра.2014.07.001

Akinsomi, O., Kola, K., Ndlovu, T. \& Motloung, M., 2016, 'The performance of the Broad Based Black Economic Empowerment compliant listed property firms in South Africa', Journal of Property Investment \& Finance 34(1), 3-26. https://doi. org/10.1108/JPIF-09-2014-0061 
Alessandri, T.M., Black, S.S. \& Jackson, W.E., 2011, 'Black economic empowerment transactions in South Africa: Understanding when corporate social responsibility may create or destroy value', Long Range Planning 44(4), 229-249. https://doi. org/10.1016/j.Irp.2011.02.002

Anwana, E.O., 2018, 'Corporate social responsibility and corporate governance: Implementation and challenges for companies listed on the Johannesburg securities exchange', PhD thesis, Department of Applied Law, Durban University of Technology.

Arafa, M.A., 2011, 'Battling corruption within a corporate social responsibility strategy', Indiana International \& Comparative Law Review 21(3), 1-24. https:// doi.org/10.18060/17658

Archer, D., 2015, Are organisations learning from their M\&E?, Trialogue, viewed 07 May 2017, from https://trialogue.co.za/wp-content/uploads/2016/08/The-CSIHandbook_2015_interactive_digital-version-for-uploadinng_final.pdf.

Babarinde, O.A., 2009, 'Bridging the economic divide in the Republic of South Africa: A corporate social responsibility perspective', Thunderbird International Business Review 51(4), 355-368. https://doi.org/10.1002/tie.20272

Bhasin, M.L., 2017, 'Integrated reporting at the crossroads: Will it become trendsetter model for the corporate reporting', International Journal of Management Sciences and Business Research 6(2), 25-59.

Bolton, P., 2011, 'New preferential procurement regulations released', Local Government Bulletin 13(3), 7

Carroll, A.B., 2008, 'A history of corporate social responsibility', in A. Crane, D. Matten, A. McWilliams, J. Moon \& D.S. Siegel (eds.), The Oxford handbook of corporate social responsibility, pp. 19-46, Oxford University Press, Oxford.

Chikulo, B.C., 2013, 'Developmental local governance and service delivery in South Africa: Progress, achievements and challenges', Journal of Social Development in Africa 28(1), 35-64.

Currie, I. \& De Waal, J., 2013, The Bill of Rights handbook, 6th edn., Juta, Cape Town.

Da Piedade, L. \& Thomas, A., 2006, 'The case for corporate responsibility: An exploratory study', SA Journal of Human Resource Management 4(2), 65-74. https://doi.org/10.4102/sajhrm.v4i2.89

Davis, D., 2020, 'Social justice and economic inclusion: Where to South Africa?', Daily Maverick, viewed 05 April 2020, from https://www.dailymaverick.co.za/ article/2020-02-23-social-justice-and-economic-inclusion-where-to-southafrica/.

Deloitte, 2017, King IV bolder than ever, viewed 27 March 2017, from https://www2 deloitte.com/za/en/pages/africa-centre-for-corporate-governance/articles/ kingiv-report-on-corporate-governance.html.

Department of Labour, 2017, Employment Equity Act, viewed 19 October 2020, from http://bee.b1sa.co.za/docs/The\%20Employment\%20Equity\%20Act\%201998.pdf.

European Commission, 2017, Better regulation guidelines (European Commission), viewed 19 March 2020, from https://www.emcdda.europa.eu/document-library/ better-regulation-guidelines-european-commission_en.

Flores-Araoz, M., 2011, 'Corporate social responsibility in South Africa: More than a nice intention', Polity, viewed 05 March 2013, from https://www.polity.org.za/ article/corporate-social-responsibility-in-south-africa-more-than-a-niceintention-2011-09-12.

Frynas, J.G. \& Yamahaki, C., 2016, 'Corporate social responsibility: Review and roadmap of theoretical perspectives', Business Ethics: A European Review 25(3), 258-285. https://doi.org/10.1111/beer.12115

Goldman, I., Deliwe, C.N., Taylor, S., Ishmail, Z., Smith, L., Masangu, T. et al., 2019 'Evaluation 2 - Evaluating the national evaluation system in South Africa: What has been achieved in the first 5 years?', African Evaluation Journal 7(1), e1-e11. https://doi.org/10.4102/aej.v7i1.400

Goldman Sachs, 2013, Two decades of freedom: What South Africa is doing with it, and what now needs to be done, viewed 05 May 2017, from http://www. goldmansachs.com/our-thinking/archive/colin-coleman-south-africa/20-yrs-offreedom.pdf.

Govender, J., 2016, 'Social justice in South Africa', Civitas - Revista de Ciências Sociais 16(2), 237. https://doi.org/10.15448/1984-7289.2016.2.23076

Hafenbrädl, S. \& Waeger, D., 2017, 'Ideology and the micro-foundations of CSR: Why executives believe in the business case for CSR and how this affects their CSR engagements', Academy of Management Journal 60(4), 1582-1606. https://doi. org/10.5465/amj.2014.0691

Hamann, R., 2005, 'Universalizing corporate social responsibility? South African challenges to the International Organization for Standardization's new socia responsibility standard', Business and Society Review 110(1), 1-19. https://doi. responsibility standard', Business and
org/10.1111/j.0045-3609.2005.00001.x

Helliker, K., Hendricks, F. \& Ntsebeza, L., 2013, 'Conference on “Land, race and nation in South Africa", University of Cape Town, Cape Town, South Africa, 19-22 June 2013', Agrarian South: Journal of Political Economy 2(3), 367-370. https://doi. org/10.1177/2277976013517201

Henrard, K., 1996, 'The internally displaced in South Africa: The strategy of forced removals and apartheid', Jura Falconis 32(4), 491-522.

Hinson, R.E. \& Ndhlovu, T.P., 2011, 'Conceptualising corporate social responsibility (CSR) and corporate social investment (CSI): The South African context', Socia Responsibility Journal 7(3), 332-346. https://doi.org/10.1108/17471111111154491

Hlakudi, J.N., 2015, 'The implementation of preferential procurement policy in Gauteng Province: Challenges and solutions', Africa's Public Service Delivery and Performance Review 3(1), 55-73. https://doi.org/10.4102/apsdpr.v3i1.75

Horwitz, F.M. \& Jain, H., 2011, 'An assessment of employment equity and broad based black economic empowerment developments in South Africa', Equality, Diversity and Inclusion: An International Journal 30(4), 297-317. https://doi.org/10.1108/ 02610151111135750
Karriem, A. \& Hoskins, M., 2016, 'From the RDP to the NDP: A critical appraisal of the developmental state, land reform, and rural development in South Africa', Politikon 43(3), 325-343. https://doi.org/10.1080/02589346.2016.1160858

KPMG, 2017a, The Companies Act 71 of 2008, viewed 01 May 2017, from http:// docplayer.net/11619439-The-companies-act-71-of-2008-kpmg-co-za.html.

KPMG, 2017b, King IV summary guide, viewed 29 May 2017, from https://assets. kpmg.com/content/dam/kpmg/za/pdf/2016/11/King-IV-Summary-Guide.pdf.

Kraak, A., 2008, 'A critical review of the National Skills Development Strategy in South Africa', Journal of Vocational Education \& Training 60(1), 1-18. https://doi. org/10.1080/13636820701828762

Louw, A.M., 2015, "'I am not a number! I am a free man!" The Employment Equity Act, 1998 (and other myths about the pursuit of "equality", "equity" and "dignity" in post-apartheid South Africa) Part 2', Potchefstroom Electronic Law Journal 18(3), 568-733. https://doi.org/10.4314/pelj.v18i3.06

Luiz, J.M. \& Stewart, C., 2014, 'Corruption, South African multinational enterprises and institutions in Africa', Journal of Business Ethics 124(3), 383-398. https://doi. org/10.1007/s10551-013-1878-9

Madlanga, M.R., 2019, 'Procurement, corruption and their relevance to, and impact on, human rights', Public Contract Law Journal 48(2), 259-277.

Mariri, T., 2012, 'Corporate social responsibility as a tool for sustainable development in Africa: How important is the context?', Polity, viewed 23 August 2013, from https:// www.polity.org.za/article/corporate-social-responsibility-as-a-tool-for-sustainabledevelopment-in-africa-how-important-is-context-2012-09-25/searchString:Corpora te+social+responsibility+as+a+tool+for+sustainable+development+in+Africa+How+ important+is+the+context.

Mersham, G.M. \& Skinner, C., 2016, 'South Africa's bold and unique experiment in CSR practice', Society and Business Review 11(2), 110. https://doi.org/10.1108/SBR04-2016-0027

Michelon, G., Boesso, G. \& Kumar, K., 2013, 'Examining the link between strategic corporate social responsibility and company performance: An analysis of the best corporate citizens', Corporate Social Responsibility and Environmental Management corporate citizens', Corporate Social Responsibility
20(2), 81-94. https://doi.org/10.1002/csr.1278

Mushariwa, M. \& Papacostantis, H., 2016, 'The impact of minority status in the application of affirmative action: Naidoo v Minister of Safety and Security 20135 BLLR 490 (LC)', Potchefstroom Electronic Law Journal 19(1), 1-25. https://doi. org/10.17159/1727-3781/2016/v19i0a1160

Mxunyelwa, S. \& Vallabh, D., 2017, 'Skills as impediment to Small and Medium Tourism Enterprises (SMTEs), Eastern Cape, South Africa', African Journal of Hospitality, Tourism and Leisure 6(4), 1-8.

Neier, A., 2013, 'Misunderstanding our mission', openDemocracy, viewed 13 September 2019, from https://www.opendemocracy.net/en/openglobalrightsopenpage/misunderstanding-our-mission/.

Prasad, A.B. \& Kumar, R.S., 2011, 'Monitoring and evaluation of csr interventions: A study of csr programs in gmr industries rajam srikakulam district', Management study of csr programs
Insight $7(2), 79-84$.

Preuss, L., Barkemeyer, R. \& Glavas, A., 2016, 'Corporate social responsibility in developing country multinationals: Identifying company and country-level influences', Business Ethics Quarterly 26(3), 347-378. https://doi.org/10.1017/ beq. 2016.42

PWC, 2016, King IV: An outcomes-based corporate governance code fit for a changing world, viewed 17 May 2017, from https://www.pwc.co.za/en/assets/pdf/king-ivsteering-point.pdf.

Radipere, S. \& Van Scheers, L., 2014, 'Investigating whether a lack of marketing and managerial skills is the main cause of business failure in South Africa', South African Journal of Economic and Management Sciences 8(4), 402-411. https:// doi.org/10.4102/sajems.v8i4.1171

Rahim, M.M. \& Alam, S., 2014, 'Convergence of corporate social responsibility and corporate governance in weak economies: The case of Bangladesh', Journal of Business Ethics 121(4), 607-620. https://doi.org/10.1007/s10551-013-1699-x

Ramlall, S., 2012, 'Corporate social responsibility in post-apartheid South Africa', Social Responsibility Journal 8(2), 270-288. https://doi.org/10.1108/17471111211234888

Rampersad, R., 2010, 'An assessment of corporate governance and HIV/AIDS in the South African corporate sector', African Journal of Business Management 4(11), 2269.

Rampersad, R., 2015, 'Monitoring and evaluation of corporate social responsibility programmes in South Africa', Risk Governance \& Control: Financial Markets \& Institutions 5(4), 314-318. https://doi.org/10.22495/rgcv5i4c2art5

Reddy, K., 2015, Social justice in South Africa: Law and the role of business, in Atiner's Conference Paper Series, no. BLE2015-1457, Athens Institute for Education and Research, Athens, Greece, June 08, 2002, pp. 1-19.

Reddy, K., 2016, 'The evolving role of business in contributing to social jusitce in South Africa in terms of legislative measures', Corporate Ownership \& Control 13(2), Africa in terms of legislative measures', Corporate
$466-473$. https://doi.org/10.22495/cocv13i2c2p8

Republic of South Africa, 'Accelerated and shared growth initiative for South Africa', Annual report, viewed 05 April 2020, from https://www.gov.za/sites/default/files/ gcis_document/201409/asgisa-2007.pdf.

Rossouw, D., 2016, 'Ethics \& corporate governance', Accountancy SA 50-51, n.p., viewed 10 July 2017, from https://www.accountancysa.org.za/special-report-thefuture-of-ethics/\#ethics.

Saiz, I. \& Yamin, A., 2013, 'Human rights and social justice: The in(di)visible link', in openDemocracy, viewed 11 September, from http://www.opendemocracy.net/ openglobalrights/ignacio-saiz-alicia-ely-yamin/human-rights-and-social-justiceindivisible-link.

Schout, A. \& Schwieter, C., 2018, Two decades of better regulation in the EU Commission - Towards evidence-based policymaking?, in Clingendael, viewe 10 July 2002, from https://www.clingendael.org/sites/default/files/2018-12/PB Better_regulation.pdf. 
Skinner, C. \& Mersham, G., 2008, 'Corporate social responsibility in South Africa: Emerging trends', Society and Business Review 3(3), 239. https://doi. Emerging trends', Society and
org/10.1108/17465680810907314

South African Government, 1996, Constitution of the Republic of South Africa, 1996 Chapter 2: Bill of Rights, viewed 05 April 2020, from https://www.gov.za/ documents/constitution/chapter-2-bill-rights\#9.

South African Government, 2019, 'Constitution of the Republic of South Africa, 1996 Chapter 2: Bill of Rights', viewed 13 August 2020, from https://www.gov.za/ documents/constitution/chapter-2-bill-rights\#25.

The Presidency, 2011, National evaluation policy framework, Department of Performance Monitoring and Evaluation, Pretoria.

Thomas, A., 2014, 'Media-reported corporate governance transgressions in broadbased black economic empowerment deals in the South African mining sector', African Journal of Business Ethics 8(2), 89-107. https://doi.org/10.15249/8-2-87

Trialogue, 2014, CSI Handbook 17th ed (2014), viewed 27 May 2017, from https:// trialogue.co.za/publications/csi-handbook-17th-ed-2014/.

Tshishonga, N., 2019, 'The legacy of apartheid on democracy and citizenship in postapartheid South Africa : An inclusionary and exclusionary binary?' Affrika: Journal of Politics, Economics and Society 9(1), 167-191. https://doi.org/10.31920/2075$6534 / 2019 / 9 n 1 a 8$
Tshitereke, C. \& Crush, J., 2001, 'Contesting migrancy: The foreign labor debate in Post-1994 South Africa', Africa Today 48(3), 48-70. https://doi.org/10.2979/ AFT.2001.48.3.48

Visser, W., 2005, 'Corporate citizenship in South Africa', Journal of Corporate Citizenship 2005(18), 29-38. https://doi.org/10.9774/GLEAF.4700.2005.su.00007

Watermeyer, R.B., 2003, 'Implementing preferential procurement policies in the public sector in South Africa: Technical paper', Journal of the South African Institution of Civil Engineering = Joernaal van die Suid-Afrikaanse Instituut van Siviele Ingenieurswese 45(3), 11-22.

Watson, M.F., 2019, 'Social justice and race in the United States: Key issues and challenges for couple and family therapy', Family Process 58(1), 23-33. https:// doi.org/10.1111/famp.12427

Waweru, N.M., 2014, 'Determinants of quality corporate governance in Sub-Saharan Africa: Evidence from Kenya and South Africa', Managerial Auditing Journal 29(5), 455-485. https://doi.org/10.1108/MAJ-07-2013-0897

Wilson, F., 2011, 'Historical roots of inequality in South Africa', Economic History of Developing Regions 26(1), 1-15. https://doi.org/10.1080/20780389.2011.583026

Young, J., 2010, 'Corporate governance and risk management: A South African perspective', Corporate Ownership \& Control 7(3), 136-145. https://doi.org/ $10.22495 / \operatorname{cocv} 7 i 3 p 10$ 